\title{
LONG-TERM OUTCOME OF PATIENTS WITH PERIPHERAL T-CELL LYMPHOMA TREATED WITH FIRST-LINE INTENSIVE CHEMOTHERAPY FOLLOWED BY AUTOLOGOUS STEM CELL TRANSPLANTATION
}

\author{
Vit Prochazka**, Edgar Faber ${ }^{\mathrm{a}}$, Ludek Raida ${ }^{\mathrm{a}}$, Tomas Papajik ${ }^{\mathrm{a}}$, Jana Vondrakova ${ }^{\mathrm{a}}$, \\ Zuzana Rusinakova ${ }^{\mathrm{a}}$, Ladislava Kucerova ${ }^{\mathrm{b}}$, Miroslav Myslivecek ${ }^{\mathrm{c}}$, Karel Indrak ${ }^{\mathrm{a}}$
}

\begin{abstract}
${ }^{a}$ Department of Hemato-Oncology, University Hospital Olomouc, Czech Republic
${ }^{b}$ Department of Pathology, Faculty of Medicine and Dentistry, Palacky University Olomouc

c PET/CT imaging centre, Department of Nuclear Medicine, University Hospital Olomouc

E-mail:vit.prochazka@fnol.cz
\end{abstract}

Received: August 27, 2010; Accepted: November 11, 2010

Key words: Peripheral T-cell lymphom/High-dose chemotherapy/Autologous transplantation/Positron emission tomography (PET)

Background. Peripheral T-cell lymphomas (PTCL) are infrequent subtypes of non-Hodgkin's lymphomas. The clinical course is aggressive and the median survival is about 2-3 years. An optimal first-line chemotherapy protocol has not been established and the role of high-dose therapy with autologous stem cell transplantation (ASCT) is still unclear.

Aim. To analyze the long-term outcome of unselected PTCL patients treated with intensive first-line chemotherapy with high-dose therapy and ASCT.

Method. Here we report our experience with 29 patients with PTCL. The histological subtypes were as follows: peripheral T-cell lymphoma, not otherwise specified $n=13$; anaplastic large cell lymphoma (ALCL) ALK-negative $n=5$; ALCL ALK-positive $n=3$; ALCL with an unknown ALK status $n=3$; angioimmunoblastic lymphoma $n=1$; hepatosplenic lymphoma $n=1$; Sézary syndrome $n=1$; and enteropathy-associated T-cell lymphoma $n=2$. The median age at diagnosis was 48 years (29-64), most patients had advanced Ann Arbor stages (22 patients, 77\%), IPI score $\geq 3$ was found in $13(45 \%)$ and PIT score $\geq 2$ in $17(59 \%)$ of the 29 patients. Eighteen patients received first-line high-dose therapy and autologous SCT consolidation; two patients were consolidated with allogeneic SCT in the 1st complete remission and one patient in the 1st relapse. Ten patients with FDG-avid lymphoma were examined with integrated Positron emission tomography/ Computed tomography (PET/CT) at the time of diagnosis and after first-line therapy, two other patients were assessed with Positron emission tomography/ Computed tomography (PET/CT) only at time of restaging.

Results. Nineteen (66\%) patients achieved complete remission, $3(10 \%)$ partial remission and $7(24 \%)$ patients failed the treatment. The overall response rate was $76 \%$. PET negativity (complete metabolic response) after therapy was achieved in 8/12 (75\%) individuals. After a median follow-up of 55.1 months, 14 (48.3\%) patients relapsed or progressed and nine patients died (lymphoma progression). Eleven patients (50\% of chemosensitive patients) survived more than 50 months. Three of the long-term survivors were treated with allogeneic SCT. The 2-year event-free survival (EFS) was $52 \%$ (95\% confidence interval [CI], 0.33-0.71); the 2-year overall survival (OS) rate reached $65 \%(95 \% \mathrm{CI}$, $0.47-0.84$ ). PET negativity was associated with a lower probability of relapse (chi-square $p=0.09$ ).

Conclusion. Our data show that intensive first-line therapy with etoposide-doxorubicine-based regimens and ASCT consolidation may lead to long-term disease control in about a half of patients with chemosensitive PTCL. Achievement PET negativity is probably an essential prerequisite for long-term complete remission.

\section{INTRODUCTION}

Peripheral T-cell lymphomas (PTCLs) are infrequent types of non-Hodgkin's lymphomas (NHLs). In Western countries they represent about $7 \%$ of NHLs ${ }^{1,2}$. The incidence of nodal T-cell lymphomas based on the data from the Czech Lymphoma Study Group (CLSG) registry is $6 \%$ (211 out of 3518 patients) ${ }^{3}$. The World Health Organization (WHO) classification recognizes three subgroups of PTCLs: nodal, extranodal and leukemic forms. Nodal PTCL's are the most frequent and comprise peripheral T-cell lymphoma, not otherwise specified (PTCL, NOS), anaplastic large cell lymphoma (ALCL) and an- gioimmunoblastic lymphoma (AIL). With the exception of ALCL ALK (Anaplastic Lymphoma Kinase) positive cases is the overall prognosis of nodal PTCL's poor ${ }^{4-6}$. Current conventional treatment modalities did not dramatically improved the outcome of patients and 5-year overall survival still remains between $30 \%$ and $35 \%$ using standard chemotherapy with second- and third-generation regimens ${ }^{7-9}$. The role and timing of high-dose therapy with autologous stem cell support (ASCT) remains unclear some studies have confirmed the survival advantage of ASCT $^{10,11}$ while others produced inconsistent results ${ }^{12,13}$. Data from the Czech national registry of (autologous) hematopoietic stem cell transplantations and the CLSG 
database show an 3-year-overall survival (OS) of $74 \%$ of PTCL patients while conventionally treated patients have a median overall survival of as few as 33 months ${ }^{14}$. Recently published phase II study data showed high efficacy of dose-dense etoposide-based regimen (CHOEP-14) with ASCT consolidation ${ }^{15}$. A high proportion of patients responded to induction therapy and recived ASCT (70\%), 3-year OS reached 57\% and 3-year PFS 48\%.

In the absence of large randomised trials for HDTASCT are prognostic factors points of interest to predict the potential benefit of patients receiving high-dose therapy. The prognostic scores like the International Prognostic Index (IPI) (ref. ${ }^{16,17}$ ) or PIT (Prognostic index for peripheral T-cell lymphoma-unspecified) (Table 2) $\left(\right.$ ref. $\left.^{18}\right)$ showed a significant impact on the outcome after HDT-ASCT in most studies ${ }^{19-21}$. However, this only reflects the fact that high-risk patients remain at high-risk even after HDT-ASCT. In some studies, the IPI and PIT failed to demonstrate prognostic value ${ }^{22,23}$. Another major factor that seemed to be significantly associated with the outcome following HDT-ASCT was remission status at time of transplantation ${ }^{24,25}$. Most studies found remission status to be an independent prognostic factor. The crucial problem in remission assessment is to recognize patients at risk of early treament failure. In 2007 were published revised response criteria, which included PET $\mathrm{scan}^{26}$. Achieving PET negativity (complete metabolic response, CMR) after therapy was found to have a strong prognostic impact in patients with diffuse large B-cell lymphoma and Hodgkin's lymphoma ${ }^{27-29}$. Yet the use and predictive power of PET/CT imaging in T-cell lymphomas remains poorly studied ${ }^{30}$.

The objective of our retrospective single-center study was to analyze the prognostic scores (IPI, PIT) significance, role of PET assessment and overall outcome of unselected patients with PTCL treated with an intensive first-line chemotherapy protocol with high-dose therapy and autologous stem cell transplantation consolidation.

Table 1. Comparison of two most frequently used prognostic scores in T-cell lymphomas: IPI ${ }^{16,17}$ and PIT $^{18}$. PIT is calculated from 4 variables: age above 60 , low performance status, elevated lactate dehydrogenase level and bone marrow involvement.

\begin{tabular}{|l|c|c|c|c|}
\hline Risk group & $\begin{array}{c}\text { IPI } \\
\text { score }\end{array}$ & $\begin{array}{c}5 \text {-year } \\
\text { OS }\end{array}$ & $\begin{array}{c}\text { PIT } \\
\text { score }\end{array}$ & $\begin{array}{c}\text { 5-year } \\
\text { OS }\end{array}$ \\
\hline Low & $0-1$ & $74 \%$ & 0 & $62.3 \%$ \\
\hline Low-intermediate & 2 & $49 \%$ & 1 & $52.9 \%$ \\
\hline Intermediate-high & 3 & $21 \%$ & 2 & $32.9 \%$ \\
\hline High & $4-5$ & $6 \%$ & $3-4$ & $18.3 \%$ \\
\hline
\end{tabular}

\section{PATIENTS AND METHODS}

Here we report our experience with 29 patients with PTCL who were diagnosed in our center between the years 2000 and 2009. The histological subtypes were as follows: peripheral T-cell lymphoma, not otherwise specified (PTCL, NOS) n=13; anaplastic large cell lymphoma (ALCL) ALK-negative n=5; ALCL ALK-positive $n=3$; ALCL with an unknown ALK status $n=3$; angioimmunoblastic lymphoma $n=1$; hepatosplenic lymphoma $n=1$; Sézary syndrome $n=1$; and enteropathy-associated T-cell lymphoma (EATL) $n=2$. All biopsies were reviewed by a reference pathologist and final diagnoses were made in compliance with the published WHO classification of lymphoid tumours ${ }^{4}$. Patient baseline clinical characteristics are summarized in a Table 2.

Table 2. Patients baseline clinical characteristics $(n=29)$.

\begin{tabular}{|l|c|c|}
\hline Sex (male-to-female ratio) & $20: 9$ & $2.2: 1$ \\
\hline Median age (range) & 48 years & $29-64$ \\
\hline $\begin{array}{l}\text { Performance status } \geq 2 \\
\text { (WHO) }\end{array}$ & $7 / 29$ & $24 \%$ \\
\hline B symptoms & $20 / 29$ & $69 \%$ \\
\hline $\begin{array}{l}\text { Advanced disease stage } \\
\text { Ann Arbor stage III+IV) }\end{array}$ & $\begin{array}{c}22 / 29 \\
\text { patients }\end{array}$ & $77 \%$ \\
\hline Bone marrow involvement & $\begin{array}{c}9 / 29 \\
\text { patients }\end{array}$ & $31 \%$ \\
\hline $\begin{array}{l}\text { Elevated lactate } \\
\text { dehydrogenase level }\end{array}$ & $\begin{array}{c}26 / 29 \\
\text { patients }\end{array}$ & $90 \%$ \\
\hline IPI score $(\geq 3)$ & $\begin{array}{c}13 / 29 \\
\text { patients }\end{array}$ & $45 \%$ \\
\hline PIT score $(\geq 2)$ & 17 patients & $59 \%$ \\
\hline Median follow-up (range) & 55.1 months & $4.4-120$ \\
\hline
\end{tabular}

\section{Treatment strategy}

Twenty-six patients underwent first-line therapy according to the sequential chemotherapy (SQ) protocol, two patients received the ProMACE-CytaBOM regimen and one patient was treated according to the modified SQ protocol. Nineteen patients received first-line highdose therapy and autologous SCT consolidation (BEAM 200); two patients were consolidated with allogeneic SCT with reduced-intensity conditioning (Flu-Mel-ATG) in the 1 st complete remission and one patient in the $1 \mathrm{st}$ relapse. Eight patients did not recived high dose therapy: five of them due to primary chemoresistant disease, one was poor stem cells mobilizer, one patient had severe comorbidities (glomerulonephritis) and one patient was not indicated due to border line age and lymphoma subtype (ALCL ALK-1+).

\section{Treatment protocols}

ProMACE-CytaBOM and BEAM 200 regimens were administred as published before ${ }^{31,32}$. The sequential chemotherapy protocol consists of 3 cycles of CHOEP21-like regimen (PACEBO), 1 cycle of an ifosfamide 


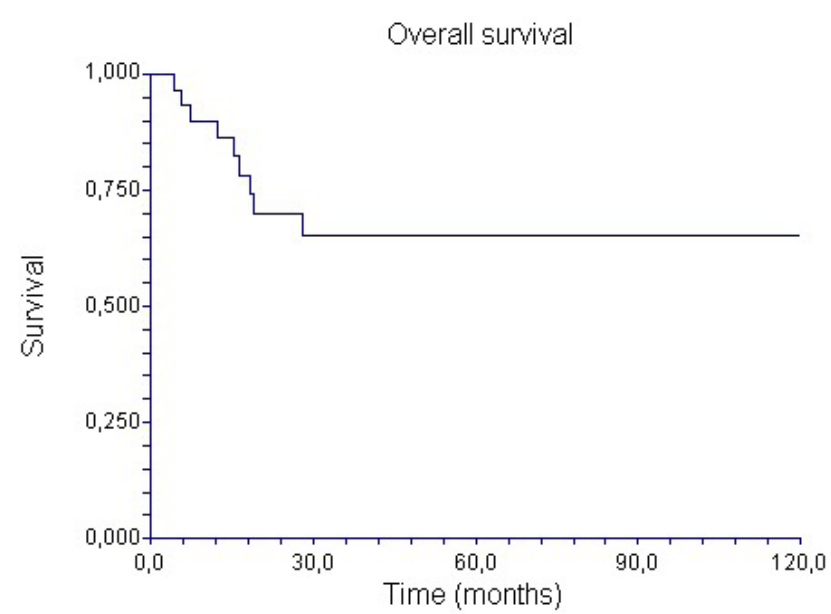

Fig. 1. Overall survival of 29 PTCL patients.

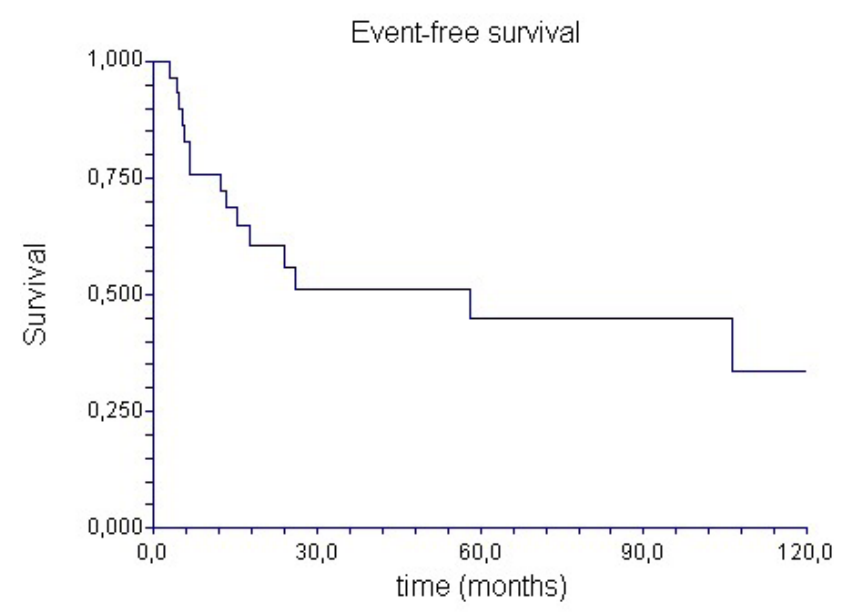

Fig. 2. Event-free survival of 29 PTCL patients.

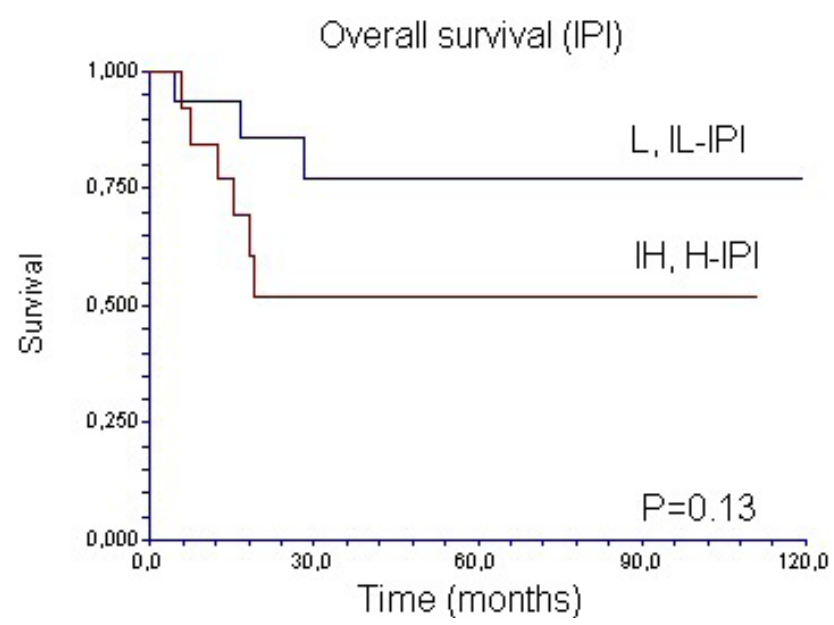

Fig. 3. Overall survival stratified by IPI score.

and methotrexate-based regimen (IVAM) and a priming regimen with high-dose cytosine arabinoside (HAM). Consolidation is provided with myeloablative conditioning (BEAM 200) and autologous stem cell support.
The PACEBO regimen was administered as follows: doxorubicin $40 \mathrm{mg} / \mathrm{m}^{2}$ intravenously day 1 , cyclophosphamide $850 \mathrm{mg} / \mathrm{m}^{2}$ intravenously day 1 , etoposide 200 $\mathrm{mg} / \mathrm{m}^{2}$ intravenously day 1 , bleomycin $10 \mathrm{mg} / \mathrm{m}^{2}$ intravenously day 8 , vincristine $1.4 \mathrm{mg} / \mathrm{m}^{2}$ (maximum $2.0 \mathrm{mg}$ ) intravenously day 8 and prednisone $40 \mathrm{mg} / \mathrm{m}^{2}$ orally days 1 to 14 . The IVAM regimen consisted of ifosfamide 1500 $\mathrm{mg} / \mathrm{m}^{2}$ intravenously days 1 to 5 , etoposide $150 \mathrm{mg} / \mathrm{m}^{2}$ intravenously day 1 to 3 , cytosine arabinoside $100 \mathrm{mg}$ / $\mathrm{m}^{2}$ intravenously day 1 to 3 , methotrexate $3 \mathrm{~g} / \mathrm{m} 2$ intravenously day 5 , mesna prophylaxis $1200 \mathrm{mg}$ intravenously days 1 to 5 , leucovorin rescue $25 \mathrm{mg} / \mathrm{m}^{2}$ intravenously from day $6 / 7$ until the plasma methotrexate level was below $0.05 \mu \mathrm{mol} / 1$. The HAM regimen was administered as follows: cytosine arabinoside $2 \mathrm{~g} / \mathrm{m}^{2}$ twice daily intravenously days 1 and 2 , mitoxantrone $10 \mathrm{mg} / \mathrm{m}^{2}$ days 2 and 3 . Stem cell mobilization was performed with $12 \mu \mathrm{g} / \mathrm{kg}$ of filgrastim given subcutaneously twice daily. The BEAM 200 conditioning regimen dosage was standard as previously published.

The treatment responses - complete response (CR), unconfirmed complete response (uCR), partial response $(\mathrm{PR})$, stable disease and progressive disease - were defined according to the International Workshop NHL Response Criteria published by Cheson ${ }^{33}$. Twelve patients with FDG-avid lymphoma were examined with integrated PET/CT (Siemens Biograph Sensation 16) at the time of diagnosis and after first-line therapy. The PET scan was defined as positive if higher than mediastinal or background activity was observed. The PET/CT scans were assessed according to the Revised International Workshop Criteria ${ }^{26}$.

\section{Statistical methods}

Our data were analyzed using the Statistical Package for the Social Sciences (SPSS, version 16) ${ }^{34}$. Overall survival (OS) was defined as the time from first treatment to the date of last follow-up examination (censored) or the date of death (event) from any cause. Progression free survival (PFS) was defined as the date of first treatment to the date of documented disease progression or death (event) or the date of last follow-up examination (censored). The Kaplan-Meier method ${ }^{35}$ was used to calculate survival probabilities. The log-rank test was used to compare differences in survival times between patient subgroups. The significance level was set at a $p=0.05$; 2-tailed tests were used in all calculations.

The EMBASE and PubMed databases were searched for literature reviews.

\section{RESULTS}

Analysis of response and survival

Nineteen (66\%) patients achieved CR, 3 (10\%) partial remission and $7(24 \%)$ patients failed the treatment. The overall response rate was $76 \%$. After a median follow-up of 55.1 months, 14 (48.3\%) patients relapsed or progressed (8 PTCL NOS; 2 ALCL ALK-positive; 2 ALCL ALKnegative; 1 Sézary syndrome; 1 EATL; median time 16.1 months) and nine patients died (lymphoma progression). 


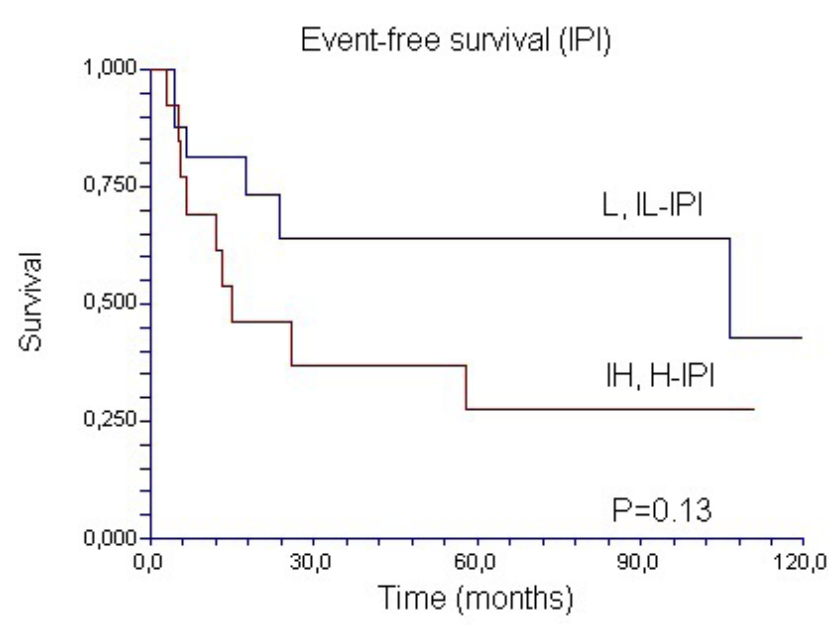

Fig. 4. Event free survival stratified by IPI score.

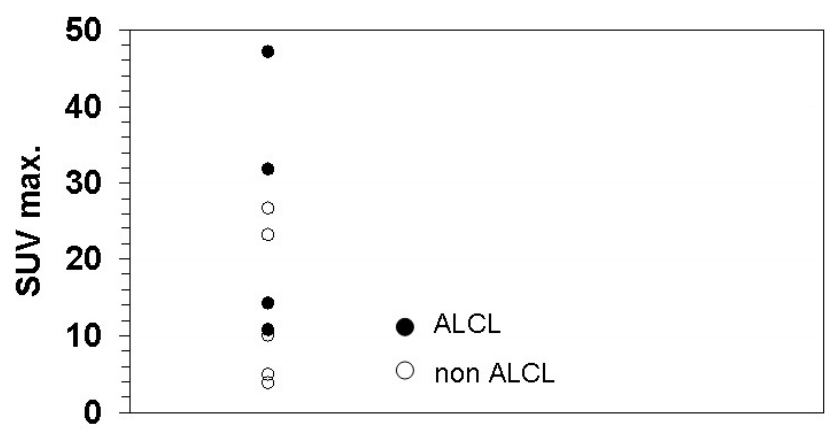

Fig. 5. Maximal standardized uptake values (SUVmax.) in PTCL patients evaluated with PET/CT scan at time of diagnosis.

The 2-year Event-free survival (EFS) was 52\% (95\%CI, $0.33-0.71)$; the 2-year overall survival (OS) rate reached $65 \%$ (95\%CI, 0.47-0.84) (Fig. 1,2). The 2-year OS of the patients with IPI score 3 and more was $52 \%$ compared to $77 \%$ in patients with low to intermediate risk IPI $(\mathrm{p}=0.13)$ (Fig. 3). The 2-year EFS was $37 \%$ in the IPI $\geq 3$ group and $64 \%$ in the lower risk group ( $\mathrm{p}=0.13$ ) (Fig. 4). A high PIT score $(\geq 2)$ did not predict 2-year OS ( $50 \%$ vs $51 \%$, p=0.68) or 2 -year EFS ( $62 \%$ vs $70 \%, p=0.56)$. Ten patients with anaplastic lymphoma (ALCL) had similar 2-year EFS to nineteen non-anaplastic patients ( $59 \%$ vs $51 \%, \mathrm{p}=0.53)$. There was no significant difference in 2-year OS between the ALCL (75\%, last event in 16.4 months) and non-ALCL group $(61 \%, p=0.55)$. Eleven patients ( $50 \%$ of chemosensitive patients) survived more than 50 months. Three of the long-term survivors were treated with allogeneic SCT. Seven long term survivors are in continuous first CR after autologous SCT.

\section{Subanalysis of PET/CT assessment}

$\mathrm{PET} / \mathrm{CT}$ was used in restaging and after therapy completion (or at time of disease progression) in ten patients with FDG avid lymphoma. Two patients were examined only at the time of restaging. PET negativity (complete metabolic response) after therapy was achieved in 8/12 (75\%) individuals, whereas 4 patients remained PET positive. After a median follow-up of 26 months 5 patients relapsed or progressed (two PET negative, three PET positive) and three patients died (2 PET positive, 1 PET negative).

PET negativity was associated with a lower probability of relapse or disease progression but the significance was borderline (chi-square $\mathrm{p}=0.09$ ). The intensity of $18 \mathrm{~F}-\mathrm{FDG}$ accumulation may be semiquantitatively determined by calculating the so-called standardized uptake value (SUV). We analyzed SUV max. in ten patients at time of diagnosis. Median SUV max. in a whole group was 14.3 (mean 17.7, range 3.8-47.1). Four patients with ALCL have higher SUV max. (median 23; mean 25.95) than six non-ALCL patients (median 12.15; mean 13.8), (Fig. 5).

\section{Toxicity of treatment}

The toxicity of the SQ treatment protocol was tolerable. Most commonly, hematologic toxicity and infections of grades III-IV according to the NCI CTC were observed. No treatment toxicity-related death occurred. No persistent treatment-related disability or severe organ dysfunction were observed. High dose therapy and autologous stem cell transplant procedure was well tolerated. Exept hematologic toxicity, only four patients experienced WHO-CTC grade III or IV (Common toxicity criteria) toxicity: two times was observed grade III gastrointestinal toxicity (mucositis, stomatitis), once grade IV gastrointestinal toxicity (stomatitis), three times grade III infection $(\mathrm{G}+$ sepsis, pneumonia, fever of unknown origin). All patiens recived granulocyte colony-stimulated factors. Median time to engraftment of neutrophils (above $1.0 \times 10^{9} / 1$ ) was 13 days (10-19), median time to engraftment of thrombocytes (above $20 \times 10^{9} / 1$ ) was 11 days (8-19). So far, no secondary malignancies have occurred.

\section{DISCUSSION AND CONCLUSION}

PTCLs still represent a heterogeneous group of aggressive lymphomas with disappointing treatment results. In most cases, conventional chemotherapy is ineffective or leads only to response with limited duration. Gisselbrecht et al. reported a 5-year OS of $35 \%$ in PTCL patients ${ }^{9}$, Escalón et al. published even worse results both in patients treated intensively or with the CHOP regimen (3-year OS of $49 \%$ and $43 \%$, respectively) (ref. ${ }^{33}$ ). The appropriate dose intensity of chemotherapy and the role of high-dose therapy with ASCT were unclear due to the heterogeneity of the studied sample and frequent inclusion of anaplastic PTCL or B-cell lymphoma subtypes ${ }^{25,36}$.

Recently, numerous clinical studies have been published that show variable effects of intensive induction therapy followed by consolidation with high-dose chemotherapy and autologous stem cell transplantation. A large retrospective study carried out by the Lymphoma Working Party of the European Group for Blood and Marrow Transplantation have confirmed the benefit of this treatment modality in patients with AIL, especially if CR was achieved after induction treatment (OS 67\% at 24 months and $58 \%$ at 48 months) (ref. ${ }^{37}$ ). In contrast, a prospective study by Mercadal et al. showed no clear benefit of 
aggressive treatment approach in first-line therapy - the use of the high-dose CHOP regimen alternating with the platinum-based ESHAP regimen is associated with significant toxicity and no real increase in the rate of complete remission $^{22}$. Rodríguez reported the effect of early ICE salvage therapy and autologous stem cell transplantation in high-risk PTCL patients, with gallium-positive scan after 3 cycles of treatment with the megaCHOP protocol and an optimistic OS at 3 years of $73 \%$ (ref. ${ }^{38}$ ). Similarly favorable results are those in Rodríguez's retrospective analysis of AIL patients with a 3-year OS of $60 \%$ (ref. ${ }^{39}$ ).

According to our experience, a significant number of patients with nodal PTCL may benefit from the intensive first line therapy and early consolidation with autologous stem cell transplantation. In our group, the overall response rate reached $76 \%$ (CR rate $66 \%$, PR rate $10 \%$ ). The chemotherapy failed in a quarter of the patients. After initial treatment, relapse or lymphoma progression occurred in half of the patients, with a median of 17.7 months. Paradoxically, treatment failed in two patients with ALK-positive ALCL. Both patients suffered from mediastinal lymphoma with primary chemoresistant course. The 2-year progression-free survival (PFS) was $52 \%$; the 2 -year overall survival rate reached $65 \%$. The toxicity of the sequential protocol was tolerable. Despite the administration of lower doses of cyclophosphamides and anthracyclines, and the absent platinum-based regimen, the protocol results in treatment outcomes comparable to those achieved by the MegaCHOP/ESHAP regimens. Beyond lower number of analyzed patients it appears that IPI score ${ }^{17}$ has more power to identify patients at risk of therapy failure, than PIT score. PET/CT assessment seems to be helpful in disease activity monitoring in T-cell lymphomas at time of restaging. Most of the T-cell lymphomas are FDG-avid and intensity of 18F-FDG accumulation (standardized uptake value, SUV) is higher than average. Patients who do not achieve metabolic response progress very rapidly, on the other hand PET negative $\mathrm{CR}$ is prerequisite for long-term CR.

To conclude, the treatment approach to younger patients with PTCL is not unified. The current first-line treatment procedures range from the classical CHOP schemes, through the MegaCHOP/ESHAP/ICE intensive toxic regimens, to high-dose chemotherapy with autologous stem cell transplantation. The administration of our novel intensive first-line sequential chemotherapy protocol with consolidation with high-dose therapy and autologous stem cell transplantation is a safe and effective treatment modality in patients with PTCL. In about half of the patient population, intensive chemotherapy with autologous stem cell transplantation offers a chance for long-term survival and may lead to improved quality of treatment response or provide time for finding a donor for allogeneic transplantation ${ }^{40}$. The survival of primary chemoresistent patients is still poor. Future advances in treating these patients will not be possible without designing prospective studies, introducing new perspective agents, immunochemotherapy ${ }^{41}$ and implementing new prognostic schemes ${ }^{18,42}$ and PET/CT assessment.

\section{ACKNOWLEDGEMENTS}

Supported by the grants of the Czech Ministry of Education (MSM 6198959205) and Czech Ministry of Health (IGA NR/9502-3) and Faculty of Medicine and Dentistry, Palacký University in Olomouc (LF-2010-004). Disclosure: Authors declare no conflicts of interests.

\section{REFERENCES}

1. Rüdiger T, Weisenburger DD, Anderson JR, Armitage JO, Diebold J, MacLennan KA, Nathwani BN, Ullrich F, Müller-Hermelink HK. Peripheral T-cell lymphoma (excluding anaplastic largecell lymphoma): results from the Non-Hodgkin's Lymphoma Classification Project. Ann Oncol 2002;13:140-149.

2. Morton LM, Wang SS, Devesa SS, Hartge P, Weisenburger DD and Linet MS. Lymphoma incidence patterns by WHO subtype in the United States, 1992-2001. Blood 2006;107(1):265-276.

3. Trněný M, Vášová I, Pytlík R, Belada D, Jankovská M, Kubáčková K, Šálková J, Kolešková E, Hofmanová Ž, Hrabětová Š, Kajaba V, Sýkorová A, Pirnos J, Přibylová, Švecová J, Čiberová J, Bolomská I, Skácelíková E, Brejcha M, Adamová D, Fraňková H, Barsová L, Benešová K, Šenigl V, Campr V, Boudová L, Střiteský J, Petrová M, Krejčová H, Procházka B, Klener P. The Non-Hodgkin's lymphoma subtypes distribution and survival in Czech Republic. Klinická onkologie 2007;20:341-348.

4. Banks PM, Warnke RA. Mature T-cell and NK-cell neoplasms. In: Jaffe ES, Harris NL, Stein H, Vardiman JW (eds): World Health Organization Classification of Tumours: Pathology and Genetics of Tumours of Hematopoetic and Lymphoid Tissues. Lyon, France: IARC Press, 2001. p.189-230.

5. Ballester B, Ramuz O, Gisselbrecht C, Doucet G, Loï L, Loriod B, Bertucci F, Bouabdallah R, Devilard E, Carbuccia N, Mozziconacci MJ, Birnbaum D, Brousset P, Berger F, Salles G, Briére J, Houlgatte R, Gaulard P, Xerri L. Gene expression profiling identifies molecular subgroups among nodal peripheral T-cell lymphomas. Oncogene 2006;25(10):1560-70.

6. Geissinger E, Bonzheim I, Krenács L, Roth S, Reimer P, Wilhelm M, Müller-Hermelink HK, Rüdiger T. Nodal peripheral T-cell lymphomas correspond to distinct mature T-cell populations. J Pathol 2006;210:172-180.

7. Savage KJ. Aggressive Peripheral T-Cell Lymphomas (Specified and Unspecified Types). In: American Society of Hematology Educational Book, USA: American Society of Hematology, 2005. p 267-277

8. Coiffier B, Brousse N, Peuchmaur M, Berger F, Gisselbrecht C, Bryon PA, Diebold J. Peripheral T-cell lymphomas have a worse prognosis than B-cell lymphomas: a prospective study of $361 \mathrm{im}$ munophenotyped patients treated with LNH84 regimen. J Clin Oncol 1990;9:45-50.

9. Gisselbrecht C, Gaulard P, Lepage E, Coiffier B, Brière J, Haioun C, Cazals-Hatem D, Bosly A, Xerri L, Tilly H, Berger F, Bouhabdallah R, Diebold J. Prognostic significance of T-cell phenotype in aggressive non-Hodgkin's lymphomas. Blood 1998;92:7682.

10. Haioun C, Lepage E, Gisselbrecht C, Bastion Y, Coiffier B, Brice P, Bosly A, Dupriez B, Nouvel C, Tilly H, Lederlin P, Biron P, Brière J, Gaulard P, Reyes F. Benefit of autologous bone marrow transplantation over sequential chemotherapy in poor-risk aggressive non-Hodgkin's lymphoma: updated results of the prospective study LNH87-2. Groupe d'Etude del Lymphomes de l'Adulte. J Clin Oncol 1997;15:1131-1137.

11. Rodríguez J, Caballero MD, Gutiérrez A, Marín J, Lahuerta JJ, Sureda A, Carreras E, León A, Arranz R, Fernández de Sevilla A, Zuazu J, García-Laraña J, Rifon J, Varela R, Gandarillas M, SanMiguel J, Conde E. High-dose chemotherapy and autologous stem cell transplantation in peripheral T-cell lymphoma: the GELTAMO experience. Ann Oncol 2003;14:1768-1775. 
12. Corradini P, Tarella C, Zallio F, Dodero A, Zanni M, Valagussa P, Gianni AM, Rambaldi A, Barbui T, Cortelazzo S. Long-term follow-up of patients with peripheral T-cell lymphomas treated upfront with high-dose chemotherapy followed by autologous stem cell transplantation. Leukemia 2006;20:1533-8.

13. Reimer P. Autologous Stem Cell Transplantation as First-Line Therapy in Peripheral T-Cell Lymphomas. European Journal of Clinical \& Medical Oncology 2010;2:117-124.

14. Prochazka V, Trneny M, Pytlik R, Vasova I, Kral Z, Belada D, Kozak T, Kubackova K, Siffnerova H, Matuska M, Lysy M, Bolomska I, Petrakova K, Otavova B, Pribylova J, Svecova J, Papajik T, Hamouzova M, Petrova M, Zapletalova J, Langova K. Peripheral T-cell lymphoma, unspecified-the analysis of the data from the Czech Lymphoma Study Group (CLSG) registry. Biomed Pap Med Fac Univ Palacky Olomouc Czech Repub 2007;151(1):103-7.

15. D'Amore F, Relander T, Lauritzen GF, Jantunen E, Hagberg H, Anderson H, Cavallin-Stahl E, Holte H, Osterborg A, Merup M, Brown P, Kuittinen O, Erlanson M, Telhaug R, Gadeberg O, Sundstrom C, Delabie J, Ralfkiaer E, Vornanen M, Jensen CB. Dose-dense induction followed by autologous stem cell transplant (ASCT) leads to sustained remissions in a large fraction of patients with previously untreated peripheral T-cell lymphomas (PTCLS) - overall and subtype-specific results of phase II study from the Nordic lymphoma study group. Heamatologica 2009;94(s2):437

16. Shipp MA. Prognostic factors in aggressive non-Hodgkin's lymphoma: who has "high-risk" disease? Blood 1994;83(5):1165-73.

17. Sonnen R, Schmidt WP, Müller-Hermelink HK, Schmitz N. The International Prognostic Index determines the outcome of patients with nodal mature T-cell lymphomas. Br J Haematol 2005;129:366-372.

18. Gallamini A, Stelitano C, Calvi R, Bellei M, Mattei D, Vitolo U, Morabito F, Martelli M, Brusamolino E, Iannitto E, Zaja F, Cortelazzo S, Rigacci L, Devizzi L, Todeschini G, Santini G, Brugiatelli M, Federico M, Intergruppo Italiano Linfomi. Peripheral T-cell lymphoma unspecified (PTCL-U): a new prognostic model from a retrospective multicentric study. Blood 2004;103:2474-2479.

19. Rodríguez J, Conde E, Gutiérrez A, Lahuerta JJ, Arranz R, Sureda A, Zuazu J, Fernández de Sevilla A, Bendandi M, Solano C, León A, Varela MR, Caballero MD, Grupo Español de Linfomas/ Trasplante Autólogo de Médula Osea, Spanish Lymphoma/ Autologous Bone Marrow Transplant Study Group. The adjusted International Prognostic Index and beta-2-microglobulin predict the outcome after autologous stem cell transplantation in relapsing/refractory peripheral T-cell lymphoma. Haematologica 2007;92:1067-74.

20. Rodríguez J, Conde E, Gutiérrez A, Arranz R, León A, Marín J, Bendandi M, Albo C, Caballero MD. The results of consolidation with autologous stem-cell transplantation in patients with peripheral T-cell lymphoma (PTCL) in first complete remission: the Spanish Lymphoma and Autologous Transplantation Group experience. Ann Oncol 2007;18:652-7.

21. Corradini P, Tarella C, Zallio F, Dodero A, Zanni M, Valagussa P, Gianni AM, Rambaldi A, Barbui T, Cortelazzo S. Long-term follow-up of patients with peripheral T-cell lymphomas treated upfront with high-dose chemotherapy followed by autologous stem cell transplantation. Leukemia 2006;20:1533-8.

22. Mercadal S, Briones J, Xicoy B, Pedro C, Escoda L, Estany C, Camós M, Colomo L, Espinosa I, Martínez S, Ribera JM, Martino R, Gutiérrez-García G, Montserrat E, López-Guillermo A, Grup per l'Estudi dels Limfomes de Catalunya I Balears (GELCAB). Intensive chemotherapy (high-dose CHOP/ESHAP regimen) followed by autologous stem-cell transplantation in previously untreated patients with in peripheral T-cell lymphoma. Ann Oncol 2008;19:958-63.

23. Reimer P, Rüdiger T, Geissinger E, Weissinger F, Nerl C, Schmitz N, Engert A, Einsele H, Müller-Hermelink HK, Wilhelm M. Autologous stem cell transplantation (autoSCT) as first-line therapy in peripheral T cell lymphomas (PTCL). Results of a prospective multicenter study. J Clin Oncol 2009;27:106-13.
24. Tarella C, Caracciolo D, Ladetto M, Zallio F, Cuttica A, Ricca I, Gavarotti P, Bergui L, Corradini P, Pileri A. 11-yr follow-up of 184 non- Hodgkin's lymphoma (NHL) patients treated with high-dose sequential (HDS) chemotherapy and autograft: highest response and best outcome in germinal-center derived subtypes [abstract]. Blood 2000;96,769a

25. Mounier N, Gisselbrecht C, Brière J, Haioun C, Feugier P, Offner F, Recher C, Stamatoullas A, Morschhauser F, Macro M, Thieblemont C, Sonet A, Fabiani B, Reyes F. Prognostic factors in patients with aggressive non-Hodgkin's lymphoma treated by front-line autotransplantation after complete remission: a cohort study by the Groupe d'Etude del Lymphomes de l'Adulte. J Clin Oncol 2004;22,2826-2834.

26. Cheson BD, Pfistner B, Juweid ME, Gascoyne RD, Specht L, Horning SJ, Coiffier B, Fisher RI, Hagenbeek A, Zucca E, Rosen ST, Stroobants S, Lister TA, Hoppe RT, Dreyling M, Tobinai K, Vose JM, Connors JM, Federico M, Diehl V. Revised response criteria for malignant lymphoma. J Clin Oncol 2007;25:579-86.

27. Haioun C, Itti E, Rahmouni A, Brice P, Rain JD, Belhadj K, Gaulard P, Garderet L, Lepage E, Reyes F, Meignan M. [18F] fluoro-2-deoxy-D-glucose positron emission tomography (FDGPET) in aggressive lymphoma: an early prognostic tool for predicting patient outcome. Blood 2005;106(4):1376-81.

28. Gallamini A, Rigacci L, Merli F, Nassi L, Bosi A, Capodanno I, Luminari S, Vitolo U, Sancetta R, Iannitto E, Trentin L, Stelitano C, Tavera S, Biggi A, Castagnoli A, Versari A, Gregianin M, Pelosi E, Torchio P, Levis A. The predictive value of positron emission tomography scanning performed after two courses of standard therapy on treatment outcome in advanced stage Hodgkin's disease. Haematologica 2006;91:475-81.

29. Terasawa T, Lau J, Bardet S, Couturier O, Hotta T, Hutchings M, Nihashi T, Nagai H. Fluorine-18-fluorodeoxyglucose positron emission tomography for interim response assessment of advancedstage Hodgkin's lymphoma and diffuse large B-cell lymphoma: a systematic review. J Clin Oncol 2009;27:1906-14.

30. Papajík T, Mysliveček M, Sedová Z, Buriánková E, Procházka V, Koranda P, Raida L, Kubová Z, Palová M, Kučerová L, Flodr P, Jarkovský J, Dušek L, Indrák K. Standardized uptake value of (18) F-FDG on staging PET/CT in newly diagnosed patients with different subtypes of non-Hodgkin's lymphoma. Eur J Haematol. 2010 Sep 28. doi: 10.1111/j.1600-0609.2010.01532.x. [Epub ahead of print].

31. Federico M, Clò V, Brugiatelli M, Carotenuto M, Gobbi PG, Vallisa D, Lombardo M, Avanzini P, Di Renzo N, Dini D, Baldini L, Silingardi V. Efficacy of two different ProMACE-CytaBOM derived regimens in advanced aggressive non-Hodgkin's lymphoma. Final report of a multicenter trial conducted by GISL. Haematologica 1998;83:800-11.

32. Colombat P, Biron P, Laporte JP, Cahn JY, Herve P, Gorin NC, Lamagnere JP, Philip T. BEAM protocol and autologous bone marrow transplantation in first chemosensitive relapse of nonHodgkin's lymphomas. Eur J Cancer 1990;26:858.

33. Cheson BD, Horning SJ, Coiffier B, Shipp MA, Fisher RI, Connors JM, Lister TA, Vose J, Grillo-López A, Hagenbeek A, Cabanillas F, Klippensten D, Hiddemann W, Castellino R, Harris NL, Armitage JO, Carter W, Hoppe R, Canellos GP. Report of an International Workshop to standardize Response Criteria for Non-Hodgkin's Lymphomas. J Clin Oncol 1999;17:1244-1253.

34. Nie HH, Hadlai H, Jenkins JG, Steinbrenner K, Bent DH. (1979) SPSS (Statistical Package for the Social Sciences). New York, NY: McGraw-Hill.

35. Kaplan EL, Meier P. Non parametric estimation from incomplete observation. JAMA 1958;53:457-481.

36. Escalón MP, Liu NS, Yang Y, Hess M, Walker PL, Smith TL, Dang NH. Prognostic factors and treatment of patients with T-cell nonHodgkin lymphoma. Cancer 2005;103:2091-8.

37. Kyriakou C, Canals C, Goldstone A, Caballero D, Metzner B, Kobbe G, Kolb HJ, Kienast J, Reimer P, Finke J, Oberg G, Hunter A, Theorin N, Sureda A, Schmitz N. High-dose therapy and autologous stem-cell transplantation in angioimmunoblastic lymphoma: complete remission at transplantation is a major determinant of 
outcome - Lymphoma Working Party of European Group for Blood and Marrow Transplantation. J Clin Oncol 2008;26:218224.

38. Rodríguez J, Conde E, Gutiérrez A, Arranz R, León A, Marín J, Bendandi M, Albo C, Caballero MD. Frontline autologous stem cell transplantation in high-risk peripheral T-cell lymphoma: a prospective study from The Gel-Tamo Study Group. Eur J Haematol 2007;79:32-8.

39. Rodríguez J, Conde E, Gutiérrez A, Arranz R, Gandarillas M, Leon A, Ojanguren J, Sureda A, Carrera D, Bendandi M, Moraleda J, Ribera JM, Albo C, Morales A, García JC, Fernández P, Cañigral G, Bergua J, Caballero MD. Prolonged survival of patients with angioimmunoblastic T-cell lymphoma after high-dose chemotherapy and autologous stem cell transplantation: the GELTAMO experience. Eur J Haematol 2007;78:290-296.
40. Corradini P, Dodero A, Zallio F, Caracciolo D, Casini M, Bregni M, Narni F, Patriarca F, Boccadoro M, Benedetti F, Rambaldi A, Gianni AM, Tarella C. Graft-versus-lymphoma effect in relapsed peripheral T-cell non-Hodgkin's lymphomas after reduced-intensity conditioning followed by allogeneic transplantation of hematopoietic cells. J Clin Oncol 2004;22:2172-2176.

41. Ravandi F, Keating M. Alemtuzumab in T-cell malignances. In: Hillmen P, Witzig TE. Immunotherapy of lymphoid malignancies. Oxford: Atlas Medical Publishing, 2005. p.189-196.

42. Went P, Agostinelli C, Gallamini A, Piccaluga PP, Ascani S, Sabattini E, Bacci F, Falini B, Motta T, Paulli M, Artusi T, Piccioli M, Zinzani PL, Pileri SA. Marker expression in peripheral T-cell lymphoma: a proposed clinical-pathologic score. J Clin Oncol 2006;24:2472-2479. 
